\title{
Riglyne vir die toerusting van ouderlinge
}

\author{
J.A. Erasmus \& B.J. de Klerk \\ Skool vir Kerkwetenskappe \\ Potchefstroomse Universiteit vir $\mathrm{CHO}$ \\ POTCHEFSTOOM \\ E-pos: ontbjdk@puknet.puk.ac.za
}

\begin{abstract}
Guidelines on equipping elders for their task

One of the biggest problems the contemporary church experiences is the fact that many believers are not spiritually equipped in an ongoing way mainly because many church officials called to do so (Eph. 4:11-12), are in many instances not adequately equipped themselves. In this article some guidelines are suggested to equip elders more efficiently for their duty. In the first instance the semantic layers of the idea to equip are investigated by analysing certain Biblical key concepts in this regard. Secondly, an overview of the background of the office of the elder is given as is outlined in the church order of the GKSA. Furthermore, the general requirements according to which the elder should implement and exercise his duties as office bearer are also highlighted. This procedure is followed in order to identify the gifts necessary for an elder to implement his pastoral care and duties effectively. Lastly, the outcome of both aspects of the investigation is considered in order to suggest possible guidelines for the office of elders.
\end{abstract}

\section{Inleiding}

Amper 2000 jaar gelede skryf die apostel Paulus in een van sy briewe die volgende aan die kerk in Efese (Ef. 4:11-12) : "En dít is die gawes wat Hy gegee het: apostels, profete, evangeliste, en herders en leraars. Sy doel daarmee was om die gelowiges toe te rus vir hulle diens en vir die opbou van die liggaam van Christus". Vandag is een van die grootste probleme wat die kerk ervaar die feit dat gelowiges nie toegerus is vir hulle roepingswerk as lede van die liggaam van Christus in hierdie wêreld nie. Lidmate word tot besondere dienste geroep, maar is nie toegerus om die besondere dienswerk te doen nie (Shawchuch \& Heuser, 1993:186). Daaruit volg dat die gelowiges dan nie toegerus word om húlle dienswerk te kan doen nie (vgl. Askes, 1993:532). 
Hendriks (1997:27-28) toon statisties aan dat die kerk vandag, veral die gevestigde kerke van Europese oorsprong, in 'n kwyn- of afbreekfase verkeer. Hy sê dat "toenemende onbetrokkenheid" die mees uitstaande kenmerk van die meeste gevestigde kerke se tradisionele bedieningspraktyke geword het. Tereg stel Hendriks dat die kerk wat in die nuwe wêreld gaan oorleef, sal bestaan uit lidmate wat op God fokus en vra na God se wil in verskillende situasies. Daarmee word bedoel dat hulle selfstandig en gefundeerd hulle geloof kan verantwoord en etiese keuses vanuit 'n Christelike waardesisteem kan maak. In kort: die kerk wat oorleef, sal bestaan uit toegeruste lidmate.

Soos uit die aanhaling hierbo uit Efesiërs 4:11-12 blyk, is die taak van die besondere dienste juis om die gelowiges toe te rus. Dit is elke gelowige se taak om betrokke te wees by die opbou van die liggaam van Christus. Sekere mense word egter afgesonder om bo en behalwe hulle dienswerk as gelowiges ook nog ander dienswerk te verrig, naamlik die toerusting van gelowiges (Adams, 1978:13). Die uitdaging tans is om die "moderne, onafhanklike mens" te help om deur die Woord en Gees op God te fokus (Hendriks, 1997:29). Die besondere dienswerker moet besef dat hy nie bloot daar is om die pastor te help om sy werk te doen nie, máár dat hy self die taak het om ander gelowiges toe te rus om hulle dienswerk te doen (Beukes, 1997: 681; Coertzen, 1995: 345). Die pastor moet homself op sy beurt nie sien as alleenwerker in diens van God in die gemeente nie, maar as medelid in die liggaam van Christus wat met die ander lede moet saamwerk om die liggaam op te bou (Nel, 1994:62-83).

Omdat hierdie so 'n omvattende navorsingsterrein is, is die fokus van hierdie artikel die toerusting en ontwikkeling van die gawes om die besondere dienswerk van ouderling te kan doen - om ouderlinge in staat te stel om gelowiges te kan toerus.

Die versoeking is groot om te probeer bepaal presies hóé besondere dienswerkers in die Bybel, en spesifiek die Nuwe Testament, toegerus is vir hulle taak. Pelser $(1990: 3,14)$ toon egter aan dat daar so 'n groot verskeidenheid fokusareas in die Nuwe Testament is met betrekking tot die bedieninge dat dit onmoontlik is om ' $n$ verteenwoordigende model of struktuur ten opsigte van toerusting te identifiseer. Verskil van tyd, andersheid van situasie, verskil in kerkbegrip en dies meer, was telkens verantwoordelik vir eiesoortige persepsies oor die bedieninge. In aansluiting hierby, stel Hendriks (1990:32) hoedat daar in die toerusting van die dienaar eerder op die ontdekking en ontwikkeling van gawes gefokus moet word.

Daarom gaan die toerusting van die ouderling in hierdie artikel soos volg benader word:

- Eerstens gaan (aan die hand van die Louw en Nida (1988) se semantiese woordeboek) gekyk word na watter verskillende woorde in die Skrif gebruik 
word om toerusting aan te dui en wat hulle presiese betekenis is - sover moontlik bepaal kan word.

- Tweedens gaan bepaal word watter gawes vandag in 'n ouderling ontwikkel moet word.

- Laastens sal oorsigtelik gepoog word om dit wat die Skrif onder toerusting verstaan (wat bepaal is in stap een) toe te pas op die ontwikkeling van die benodigde gawes van die ouderling (wat bepaal is in stap twee).

\section{Wat die Bybel met toerus bedoel (Stap 1)}

Wat is die betekenis van toerus, leer en onderrig in die Bybel? In hierdie deel van die artikel gaan eerstens ondersoek word wat in Efesiërs 4:12 bedoel word met toerus. 'n Semantiese woordstudie sal moontlik meer duidelikheid gee. In die tweede en derde plek gaan ook semanties ondersoek word watter begrippe gebruik word om leer en onderrig aan te dui en wat dit beteken.

\subsection{Toerus (katartismo/j)}

Katartismo/j is die woord wat in Efesiërs 4:12 gebruik word en in Afrikaans met "toe te rus" vertaal is. Die woord omskryf dit wat die besondere dienswerkers moet doen. Volgens Louw en Nida se semantiese woordeboek (1988, 1:680) val die betekenis van hierdie woord in semantiese veld 75 . In veld 74 word vlakke van bekwaamheid gestel waar daar onsekerheid is of die subjek bekwaam is om dit te doen wat van hom verwag word. Daarteenoor, in veld 75 is die betekenis om vlakke van bekwaamheid aan te dui waar daar sekerheid van die bekwaamheid is - waar die subjek in staat is om dit te doen waarvoor hy bekwaam is.

Rienecker (1980:185) maak die stelling dat hierdie woord meestal in 'n mediese konteks gebruik is en dan die spalk van 'n gebreekte been aangedui het. Soos 'n gebreekte been gespalk moet word om dit weer bruikbaar te maak vir die liggaam en dit in harmonie te bring met die ander ledemate, so moet die gelowige deur toerusting gebring word tot diensbaarheid in die liggaam van Christus (vgl. Vorster, 1997:277). Coertzen (1995:345) sê dat die woord iemand of iets aandui wat in staat gestel word om te doen wat van so iemand of iets verwag word. So word dit byvoorbeeld gebruik om die toerusting van skepe vir hulle vaart aan te dui óf die oefening van 'n leër om slaggereed te wees.

Roberts (1990:120) sê dat die gedagte wat Paulus in Efesiërs wil oordra, dié is van bekwaammaking. Die lede van die kerk moet bekwaam gemaak word sodat hulle hul diens kan uitvoer. Volgens hom kan die betekenis die beste weergegee word met die gedagte van opleiding. 
Hieruit word dit dus duidelik dat katartismo/j in Efesiërs 4:12 die betekenis het van om gelowiges op te lei (die toerusting te verskaf) sodat hulle ten volle in staat sal wees om

- hulle dienswerk in die liggaam van Christus te doen en dus

- ook sal kan werk tot die opbou van die liggaam van Christus.

Eenvoudig gestel in terme van die mediese beeld hierbo gebruik: om daardie lidmate wat nie meer as lede van die liggaam funksioneer nie of verkeerd funksioneer, te spalk en tot die regte funksionering te bring (Coertzen, 1995:345-346). Net so word die ouderling gedurende die toerustingstaak "gespalk" sodat hy reg kan funksioneer en gelowiges doeltreffend toerus.

\subsection{Leer}

Verskillende Griekse woorde word gebruik om die proses van leer aan te dui. Vir hierdie artikel word gefokus word op die prosesse waardeur die besondere dienswerker gaan om in staat te wees om dit waarvoor hy geroep is, suksesvol te kan doen. Daar word dus gekonsentreer op woorde wat hierdie proses steun.

Louw en Nida (1988,1:325-334) beskryf in veld 27 die prosesse van leer: Leer is die proses om kennis in te samel, kennis wat voorheen onbekend was (27.1-4). Hierdie kennis kan ingesamel word deur iets uit te vind of deur iets te bevestig (27.5). Die fokus van die leerproses kan wees op die bron van die inligting (27.6), óf op die leerproses self (27.7). Leer is ook nie net 'n eenmalige handeling nie, maar kan later voortgesit word as meer en duideliker inligting benodig word (27.8). Dit word ook duidelik dat om presiese inligting te verkry daar op 'n noukeurige manier te werk gegaan moet word (27.9) en dat daar soms heelwat moeite gedoen moet word om die inligting te verkry (27.10).

Inligting kan verkry word deur vrae te vra en navraag te doen (27.11). Hierdie vrae kan spesifiek in 'n onderwys-/instruksieproses gevra word (27.12), maar ook in 'n tradisionele oorleweringsproses geskied (27.13). Nog 'n manier waarop inligting verkry kan word, is deur persoonlike ervaring (27.14). In die Bybel vind ons verskillende maniere waarop kennis aangeleer is. Daar was formele onderrigsituasies (bv. Saulus aan die voete van Gamaliël [Hand. 22:3]) en informele onderrigsituasies (bv. ouers wat die opdrag kry om die wet van die Here voortdurend by hulle kinders in te skerp [Deut. 6:7]).

Leer kan dus saamgevat word as die "spalk" wat gebruik word om die ouderling tot regte funksionering te bring. Die "spalk" kan baie verskillende vorme aanneem, waaronder: formele en informele kennisverwerwing/ kennisbevestiging asook die gebruikmaak van eenmalige en voortdurende leergeleenthede. 


\subsection{Onderrig}

Louw en Nida (1988, 1:413-416) plaas onderrig onder die hoofdomein van kommunikasie. Woorde wat in die verband gebruik kan word, kom voor in dié velde 33.224 tot 33.250 .

Om mense toe te rus, is om hulle te onderrig. Onderrig vind plaas in 'n formele óf informele opset (33.224), en kan gesistematiseer word (33.225). Die doel van onderrig is om behoorlike gewoontes en wyses van optrede aan te leer (33.226, $33.231,33.242)$. Onderrig vind ook plaas met die doel om instruksies te gee van wat om te doen (33.230), korrekte gedrag aan te leer en godsdiens reg te beoefen (33.231). In veld 33.232 word die pragtige idioom behandel wat beskryf hoe die persoon wat onderrig word aan die voete van sy leermeester sit terwyl die leermeester breedvoerige onderwysing verskaf. Die onderwyser kan toerus deur dit oor te dra wat self aan hom as iets nuuts oorgedra is (33.238; 1 Kor. 11:23), of dit wat aan hom deur tradisionele oorlewering oorgedra is (33.240).

Firet (1974:72-78) toon aan dat die doel van onderrig nie is om net ' $n$ inleiding tot spesifieke kennis te gee nie, maar ook dat dit die begeleiding op die weg van, en in die versameling van kennis is sodat die een wat toegerus word, vas kan staan in die waarheid.

Die voorbeeld van die leermeester speel die belangrikste rol in die toerusting van die leerling (vgl. Shawchuck \& Heuser, 1993:78; 1 Pet. 5:3). Die leerling wat aan die voete van sy leermeester sit, sien in die leermeester se optrede ' $n$ rol waarmee hy hom kan identifiseer. Die leermeester moet dus daarvan bewus wees dat sy woorde wek maar sy voorbeelde trek. Dit wat hy doen, gaan sy leerling ook doen.

Wat dus duidelik na vore kom, is dat die persoon wat die onderrig behartig 'n grondige kennis moet hê van dit wat hy onderrig en hierdie kennis moet kan kommunikeer. Die toeruster moet 'n spesialis moet wees in die rigting waarin hy toerusting aanbied en 'n navolgenswaardige voorbeeld kan stel (33.243 tot 33.249).

\subsection{Sintese tussen "toerus", "leer" en "onderrig"}

Volgens Efesiërs 4:11,12 moet gelowiges toegerus word sodat hulle in staat sal wees om hulle dienswerk in die liggaam van Christus te doen en ook die liggaam van Christus te kan opbou.

- Toerusting vind deur besondere dienswerkers plaas wat bekwaam is om die onderrig te kan gee. Tog, net soos die gelowiges toegerus (gespalk) word, so moet die dienswerkers ook toegerus word voor hulle self andere kan toerus (spalk) en tot doeltreffende funksionering in die liggaam van Christus bring. 
- Die persoon wat toegerus word, is in 'n leerproses en hy doen óf nuwe kennis op, óf bevestig dit waaroor daar onsekerheid was sodat hy vas kan staan in die waarheid.

- Die leerproses is nie net 'n eenmalige handeling nie, maar gaan voort soos nuwe kennis/inligting benodig word.

- Dit is duidelik dat moeite gedoen moet word om toerusting te verkry. Die proses kan deur tradisionele oorlewering geskied óf deur iemand wat dit formeel en/of informeel onderrig.

\section{Die ouderling se gawes wat ontwikkel en toegerus moet word (Stap 2)}

Dit is ook nodig om te kyk na die gawes wat by die ouderling teenwoordig moet wees om sy dienswerk te kan verrig sodat hy getrou aan sy opdrag in Efesiërs 4:11-12 ander gelowiges kan toerus.

\subsection{Die toeruster van die ouderling}

Reeds is gesien dat die doel van die besondere dienswerkers is om die gelowiges vir hulle werk toe te rus. Wie het dan die taak om die besondere dienswerkers toe te rus? Hierbo (2.3) is gesien dat die toeruster 'n spesialis moet wees op die gebied waarin toerusting aangebied word. Dit is daarom die verantwoordelikheid van die herder en leraar om ouderlinge en diakens toe te rus vir hulle dienswerk. Vanuit die aard van sy opleiding en dienswerk is die herder en leraar 'n spesialis in die toerusting van gelowiges en daarom moet hy besondere dienswerkers identifiseer en toerus (Nel, 1994:79-80).

Firet (1974:79-80) noem ook dat die enigste leermeester wat met gesag kon leer (en toerus), die Here Jesus Christus was. Die enigste gesagvolle lering wat ons vandag besit, is die Woord van God. Die herder en leraar is toegerus, geroep en bevestig in die gemeente juis om die Woord van God te verkondig. Hy het dus die kennis om andere Bybelsgefundeer te kan toerus (vgl. Beukes, 1997:687; Raubenheimer, 1987:45-46). Vanuit sy kontak met die gemeente weet hy wat die leemtes is wat in toerusting gehanteer moet word en kan hy die pad aanwys vir toerusting (Shawchuch \& Heuser, 1993:188, 201-203).

\subsection{Watter gawes ontwikkel moet word}

Een van die merktekens van die ware kerk is dat die kerk apostolies is. Van Genderen en Velema (1992:654) sê apostolisiteit beteken dat die kerk in 'n besondere verhouding tot die apostels en hulle werk staan. Die werk van die kerk is deur die apostels bepaal (soos hulle deur die Heilige Gees geïnspireer is) en daarom moet die kerk die stempel van die apostel dra en bly dra. Omdat die 
apostels die grondvesters van die kerk was - die fondament daarvan gelê het (1 Kor. 3:10) - moet daarom gekyk word na wat die Here ons deur die apostels in die Skrif leer oor watter gawes vir die besondere dienste benodig word.

\subsubsection{Die agtergrondsgegewens oor die diens van ouderling}

In die Griekse Nuwe Testament word twee woorde gebruik vir die Afrikaanse vertaling van ouderling. Alhoewel daar semanties tussen die twee woorde onderskei kan word (vgl. velde 53.71 en 53.77 in Louw en Nida, 1988, 1:542), word die standpunt in dié artikel gehuldig dat hierdie twee woorde bloot sinonieme is wat op dieselfde diens dui (Kleynhans, 1984:56; vgl. Grosheide, 1950:111, 115) en daarom word daar nie 'n onderskeid tussen dié woorde getref nie.

Dit word duidelik as die ontwikkeling van die diens van ouderling nagespeur word, dat hierdie besondere diens vanuit die bekende verskynsel van oudste in die $\mathrm{Ou}$ Testament ontwikkel het (Kleynhans, 1984:53-55). As die Here Moses beveel om die berg op te klim, moet hy ook deur sewentig van die oudstes van Israel vergesel word (Eks. 24:1). Die begrip oudste impliseer die gedagte van ervarenheid, eerbiedwaardigheid en invloed. Hulle was die patriargale leiers wat hulle outoriteit verkry het uit die wysheid van ervaring en hulle het meestal as 'n raad saamgewerk (Aitken, 1997:1137-1139).

Deur die eeue het die oudste ' $n$ steeds belangrike plek in die samelewing bly speel - selfs na die ballingskap. Met verloop van tyd het sinagoges ontwikkel en het elke sinagoge 'n plaaslike beheerraad van oudstes verkry. Daarom is dit ook niks snaaks dat op dieselfde plek in die Bybel waar die volgelinge van Christus die eerste keer Christene genoem word, die leiers van die gemeente oudstes/ ouderlinge genoem word nie (Hand. 11:26, 30) (vgl. Marshall, 1991:159-160).

Alhoewel daar nêrens in die Nuwe Testament op een plek 'n volledige reglement vir die dienswerk van die ouderling gegee word nie is daar tog genoeg gegewens om, wanneer dit saamgevoeg word, 'n goeie geheelbeeld van 'n diensomskrywing vir ouderlinge te kry (Kleynhans, 1984:62). Voorskrifte vir ouderlinge word onder andere in 1 Timoteus 3:2-7 en 1 Petrus 5:2-3 gevind.

Roberts (1990:118) toon aan dat Paulus die herderfunksie met die diens van ouderling verbind - die herderstaak wat Jesus aan Petrus opgelê het in Johannes 21:15-17. Hy (Roberts, 1990:118) wys op die interessante dat tydens die ontmoeting van Paulus met die ouderlinge van Efese (Hand. 20:28) hy hulle vermaan om as herders die kudde van Christus te versorg waaroor die Heilige Gees hulle aangestel het. Die diens van ouderling vervul dus by uitstek die herdersfunksie in die gemeente. 
Opsommend kan oor die gawes van die ouderling die volgende gesê word - met inbegrip van die Nuwe-Testamentiese besonderhede in 1 Timoteus 3 en 1 Petrus 5 (vgl. Towner, 1994: 81-90; Marshall, 1991:158-164):

- Die ouderling moet 'n roepingsbewuste, onberispelike, voorbeeldige lewe moet lei en

- die vermoë hê om mense toegewyd Skriftuurlik te kan onderrig.

- Hy moet as leier bewus wees van sy dienaarskap in die kerk,

- nugter kan dink en

- vrede najaag.

- Hy moes al gegroei het in die geloof

- en sy algemene optrede in die samelewing moet respek afdwing.

In die Bybel word nie eksplisiet genoem dit wat die ouderling moet doen nie, maar wel die standaard wat van hom verwag word (Towner, 1994:82). In die volgende paragraaf sal gesien word hoe dit wat van die ouderling moet doen (sy taak) in 'n kerkorde omskryf word.

\subsubsection{Die taakomskrywing van die ouderling}

\subsubsection{Die taak van die ouderling}

Volgens Bouwman (1928:549) behels die dienswerk van ouderlinge volgens die Dordtse kerkorde (art. 23) die volgende:

- Die regering en tug van die gemeente

- Toesig oor mededienaars en medewerkers

- Huisbesoek

'n Vierde aspek van die dienswerk kom na vore in die Kerkorde van die Gereformeerde Kerke in Suid-Afrika (Die Dordtse kerkorde soos gewysing deur die sinodes van die Gereformeerde Kerke in Suid-Afrika): die ouderling het die taak om ook andere tot die Christelike geloof op te wek. Hierdie bepaling moet gesien word in die lig van die algemene roeping van elke gelowige om profeet te wees en die evangelie van God te verkondig (Spoelstra, 1989:147). Tog is hierdie 'n aspek van die dienswerk wat gawes vereis en wat ontwikkel moet word.

Swanepoel (1996:105-107) stel dat bogenoemde dienswerk van die ouderling onder vier basiese take tuisgebring kan word. Die take omskryf nie 'n spesifieke handeling byvoorbeeld huisbesoek nie, maar omskryf die wesenseie of kern van die ampstaak: 
- 'n Pastorale taak - die ouderling se dienswerk is gerig op die welsyn van die gemeentelede in die algemeen, maar toegespits op die welsyn van die individuele lidmaat (1 Tess. 5:12; Tit. 1:9; Jak. 5:13).

- 'n Didaktiese taak - die lidmaat moet onderrig word sodat hy in staat sal wees om die verlossing van Christus en die konsekwensies daarvan deur woord en daad te kan uitleef (1 Tim. 3:2; 1 Tim. 5:17).

- 'n Regeertaak - hier word primêr gefokus op die regering van Christus in sy kerk. Hieronder kan verstaan word: beplanning, organisering, administrasie en beheer (1 Tim. 3:4-5.

- 'n Kerugmatiese taak - hier gaan dit primêr oor die verkondiging van die Woord (1 Tim. 5:17).

Vanuit hierdie takomskrywing kan die gawes wat die ouderling benodig, afgelei word. Hierdie gawes word vervolgens saamgevat deur 'n sintese te maak tussen die gespesifiseerde take vanuit die Kerkorde van die Gereformeerde Kerke in Suid-Afrika en die take wat deur Swanepoel (1996:105-107) onderskei word.

\subsubsection{Gawes wat die ouderling benodig - afgelei vanuit sy taak}

Die Here gee aan sy kerk en ook aan elke gelowige gawes (vgl Ef. 4:7; 1 Kor. 12:11; Rom. 12:6). Die bedoeling is dat hulle die Here en ook mekaar met hierdie gawes moet dien (Coertzen 1995:348). Daarom is die eerste gawe wat noodsaaklik vir enige dienswerk is, máár veral vir die diens van regering, die gawe van diensbaarheid. God laat immers juis sy koninkryk kom langs die weg van die diens aan Christus en Christus-gemotiveerde diens in en aan die wêreld (Burger, 1991:125; Nel, 1994:33-36).

Vir die dienswerk van regering en tug oor die gemeente is dit nodig om 'n deeglike kennis van die grondslag van die kerk en die kerk self te hê. Daarom moet die ouderling daarmee moeite doen om die Skrif beter te leer ken en homself voortdurend in Skrifstudie te verdiep. Daarby moet die ouderling self deeglik kennis dra van die belydenisskrifte en die inhoud daarvan. Kennis van die ordelike weg van optrede in die kerk van Christus (vgl. 1 Kor. 14:40) is ook uiters noodsaaklik.

In sy pastorale dienswerk (waaronder: deeglik toesighou oor mededienaars) is kennis van die Skrif weer eens onontbeerlik. Die doel van pastorale dienswerk is immers om die Woord van God suiwer in die lewens van gelowiges te bedien. In die toesighouding oor mededienaars sal dit gebeur dat die ouderling een of ander tyd 'n mededienaar oor 'n saak sal moet vermaan. Om die mededienaar op so 'n wyse te vermaan dat God daardeur verheerlik word, verg goeie mense- 
verhoudings en goeie kommunikasiegawes. Die ontwikkeling van menseverhoudings en kommunikasiegawes blyk daarom noodsaaklik te wees.

Dieselfde wat vir die toesig oor mededienaars geld, geld vir huisbesoek en die didaktiese taak van die ouderling. Deur huisbesoek te doen, word die Woord aan lidmate in hulle persoonlike omstandighede bedien. Om waarlik tot lidmate deur te dring, om Christus waarlik aan die gelowiges te kan bedien sodat die Woord tot die lidmate kan spreek en hulle toegerus word, verg goeie kennis van die Skrif (om die gelowige te kan bedien en toe te rus), goeie mensekennis (om nood te kan identifiseer en te leer) en goeie kommunikasievermoëns (om die Skrifboodskap suiwer te kan oordra).

Vir die kerugmatiese taak om die Woord van God te verkondig en om die Christelike geloof by andere te kan opwek, moet die gelowige die vrymoedigheid hê om die Woord te kan oordra. Vrymoedigheid kan slegs kom as die ouderling die boodskap van die evangelie sy eie gemaak het en ook die nodige kennis het om andere met die Woord te gaan bedien. In aansluiting hierby sal kennis van dwaalleer en vals godsdienste sy taak vergemaklik om verkeerdhede reg te stel.

Laastens sal 'n ouderling slegs van sy dienswerk 'n sukses kan maak as diegene wat hy bedien, kan sien dat hy dit wat hy verkondig sy eie gemaak het. Sy spiritualiteit moet duidelik sigbaar wees vir die mense wat hy bedien - hulle moet sien dat hy uitleef wat hy verkondig (Beukes, 1997:682; Shawchuch \& Heuser, 1993:78). Jakobus toon in sy brief (Jak. 2:18) aan dat die gelowige se geloof sigbaar word vanuit die dade wat hy doen. Daarom moet die besondere dienswerker moeite doen om onberispelik te lewe (1 Tim. 3:1-7). As dienaarleier in die kerk, is dit belangrik dat die ouderling weet hoe om as leier te kan optree. Gevolglik sal die ontwikkeling van leierskapsvaardighede ook aandag moet geniet.

\subsubsection{Samevattende gedagtes oor die gawes wat ouderlinge moet hê}

Dit is duidelik dat die ouderling in die liggaam van Christus diensbaar moet wees. Dit doen hy as hy sy kennis van die Skrif, belydenis en kerkorde deur goeie kommunikasievermoëns so in mense se lewens bedien dat die liggaam van Christus daardeur opgebou word. Hierdie taak kan slegs plaasvind as daar goeie menseverhoudings is en die gelowiges die ouderling aanvaar as dienaar (wat leiding neem) en deur God gestuur is. Die dienaar moet daarom deur 'n onberispelike lewe sy roeping bevestig. So ontmoet die gelowige vir Christus in die persoon van die ouderling.

Uit die voorafgaande blyk dit dat die gawes vir die diens van ouderling in twee groepe gedeel kan word: kennis en vermoëns. 
- Kennis is die agtergrond wat nodig is om bediening te laat plaasvind. Kennis sal onder andere die volgende impliseer: Skrifkennis (waaruit kennis van die belydenis en kennis van die ordelike weg voortvloei), teoretiese kennis van hoe om die Woord te bedien in verskillende situasies, teoretiese kennis van wat Christelike leierskap/dienaarskap behels asook kennis van organisering, beplanning en administrasie.

- Vermoëns is die praktyk wat gebou word op die kennis wat bestaan. Vermoëns wat ontwikkel moet word, is daarom: vrymoedigheid om die Woord te bedien, spiritualiteit, goeie kommunikasievermoëns en interpersoonlike verhoudings.

\section{Toerusting van die ouderlinggawes (Stap 3)}

In hierdie deel van die artikel gaan sommige van die insigte wat in 2 en 3 verkry is, saamgevoeg word om enkele riglyne te gee vir die toerusting van die ouderling.

\subsection{Ontwikkeling van die gawes van kennis}

Die ontwikkeling van gawes van kennis vind plaas deurdat die oudeling in 'n leersituasie gestel word sodat hy die nodige kennis kan opdoen. In 2.2 is gesien dat 'n leerproses plaasvind deurdat iets wat onbekend was, bekend word, óf deur iets wat reeds bekend was, te bevestig. Dit is belangrik om te onthou dat die verkryging van kennis nie ' $n$ eenmalige handeling is nie, maar dat dit voortdurend kan en moet plaasvind. Ook vind die oordrag van kennis in formele en informele situasies plaas.

\subsubsection{Kennis van die Skrif, belydenis en die ordelike weg}

In 2 Timoteus 3:14-16 word die belangrikheid van die Skrif verduidelik. Daar staan dat kennis van die Skrif nuttig is tot lering, tot weerlegging, tot teregwysing, (en) tot onderwysing in die geregtigheid. Hierdie woorde omvat die hele taak van die ouderling. Kennis van die Skrif vorm dus die ruggraat van al die gawes wat by die ouderling teenwoordig moet wees (vgl. Vorster, 1999:46).

Om kennis van die Skrif op te doen, is eerstens die plig van die ouderling self. Tog speel die predikant as toeruster van die besondere dienswerker (vgl. 3.1) 'n groot rol. Kennis van die Skrif word nie eenmalig opgedoen nie. Dit is 'n voortdurende proses wat deurentyd Skrifstudie vereis - Skrifstudie wat deur die Heilige Gees verlig word. Deeglike Skrifstudie poog om die hele inhoud van die Skrif te dek - en dit kan slegs plaasvind as studie gesistematiseerd is. Die predikant (as spesialis) kan daarom baie help deur vir die ouderlinge 'n gesistematiseerde Skrifstudieprogram daar te stel sodat hulle Skrifkennis stelselmatig kan vermeerder (vgl. Raubenheimer, 1987:48). 
Kennis word ook opgedoen in formele onderrigsituasies (vgl. 2.3). Formele situasies moet geskep word vir die toerusting in Skrifkennis, belydeniskennis en kennis van die ordelike weg (Raubenheimer, 1987:48). So 'n formele situasie kan byvoorbeeld gereelde groepsbybelstudie vir ouderlinge wees. Die voordeel hiervan is dat die ouderlinge mekaar dan toerus en so die werkslas van die predikant verminder. Bywoning van 'n Bybelskool sal ook help om kennis te vermeerder.

In hierdie informele en formele Skrifstudieprogramme moet daar praktykgerigtheid wees. Die gekompliseerde werklikheid waarbinne ons leef noodsaak 'n uitbreiding van praktiese teologiese kennis (Pieterse, 1992b:334). Die ouderling moet leer om te kan sien hoedat die belydenis op die Skrif gebou is en hoe die ordelike kerklike weg vanuit die Skrif geleer word.

\subsubsection{Kennis van wat leierskap/dienaarskap behels}

Oor Christelike leierskap kan daar baie gesê word (vgl. Nel, 1994:59). Hierdie artikel spits hom net kortliks op die volgende toe:

In die kerk van Christus is daar net een hoof en dit is Christus self - Hy kan deur niemand vervang word nie (Nel, 1994:60; Vorster, 1999:36). Daarom is al die gelowiges in die kerk gelyk en word geen diens bo 'n ander gestel nie. Die gesag wat die besondere dienste uitoefen, is die gesag van Christus wat Hy aan hulle toevertrou het. Die leier in die kerk is dus in die eerste plek 'n man van God, nie 'n bestuurder of 'n professionele spesialis nie (Hendriks, 1997:33).

Nel (1994:62) stel dat leierskap in die Bybel in terme van diens gedefinieer word. Die identiteit van 'n Christenleier is dié van 'n dienskneg want in elke vorm van bediening gaan dit primêr om diens. Jesus karakteriseer sy eie bediening in terme van dienslewering: Hy het gekom om te dien en sy lewe te gee as losprys vir baie mense (Matt. 20:28). Hierdie ingesteldheid geld ook vir ouderlinge as regeerders van die gemeente. Hulle moet nie wil oorheers in hulle regering nie, hulle moet wil dien. Die praktiese uitlewing en onderrig van diensbaarheid in ' $n$ informele situasie is hier opvallend. Dienaars in die besondere dienste moet gedurigdeur opgeskerp word in die besef van hulle diensbaarheid in die toerusting van die gemeente. Verder, om in ooreenstemming met God se wil, saam met die gemeente, doelwitte te formuleer en met die lidmate saam te werk om dit te bereik (Nel, 1994:68).

Een verdere vereiste vir leierskap val deurentyd op: 'n leier is 'n persoon met visie, iemand met 'n vergesig, 'n doel, 'n mikpunt wat hy nie slegs aan ander kan kommunikeer nie, maar hy kan ook ander tot die bereiking of verwerkliking daarvan aanvuur (Van Niekerk, 1992:127, Nel, 1994:70). Tydens die toerusting van ouderlinge as leiers in die kerk moet daar aandag gegee word aan hierdie visie. Die ouderling moet besef dat hy nie maar net in die kerk werk nie, daar is 
'n doel waarna hy streef: goed toegeruste gelowiges in die koninkryk van God, met hom as instrument wat moet toerus.

\subsection{Ontwikkeling van vermoëns tot uitoefening van die dienswerk van die ouderling}

Dit spreek vanself dat daar 'n baie noue band tussen die ontwikkeling van "kennis" en die toepassing daarvan in die praktyk is. Noudat na enkele riglyne gekyk is hoe om kennis by die ouderling te ontwikkel, gaan vervolgens aandag gegee word aan die ontwikkeling van noodsaaklike vermoëns om die Woord oor te dra.

\subsubsection{Spiritualiteit}

Wat is spiritualiteit? Shawchuck en Heuser (1993:39) definieer spiritualiteit as: "the means by which we develop an awareness of the Spirit of God in us and the processes by which we keep that awareness alive and vital, to the end that we become formed in the Spirit of Christ." Beukes (1997:682) sê spiritualiteit is om midde in die gefragmenteerde lewe van hierdie tyd deur die leiding van die Gees te lewe.

Die motief van Coram Deo ('n lewe voor die aangesig van God) was baie sterk in die tyd van die Reformasie (Burger, 1995:72-77). 'n Lewe Coram Deo is 'n spirituele lewe en die hart van die Christelike bediening. In die vorige punt is gesien dat ouderlinge diensknegte is en die gesindheid van diensknegte moet hê. Slegs deur die werking van die Gees kan hulle hierdie dienskneggesindheid besit (Nel, 1994:63). Eers as kerkleiers Coram Deo lewe, kan hulle waarlik die gemeente bedien en lidmate toerus (Beukes, 1997:683). Daarom moet ook moeite gedoen word om ouderlinge toe te rus om spiritueel te lewe.

'n Deel van die toerusting van die ouderling is dus om spiritualiteit by hom te bevorder. Shawchuch en Heuser (1993:36-54) gee enkele riglyne om spiritualiteit te bevorder:

- Leer hoe om sinvolle selfondersoek te doen - sonder selfkennis kan daar geen kennis van God wees nie en sonder kennis van God kan daar geen selfkennis wees nie (vgl. Calvyn Inst. 1.1.1).

- Tyd moet so benut word dat persoonlike verhoudingbou met God kan plaasvind. Slegs vanuit die opbou van hierdie persoonlike verhouding kan ware bediening plaasvind.

- Die bewustheid van diepe afhanklikheid voor God moet bestaan. Dit beteken nie om met die Woord besig te wees om in die eerste plek ander mense daarmee te bedien nie, maar om te dien tot uitbreiding van eie spiritualiteit. 
- Deurlopende koinonia met ander gelowiges moet nagestreef word - wanneer dit moeilik gaan, is dit altyd vertroostend om te weet dat daar medegelowiges is wat jou ondersteun. Geestelike gesprekke met medegelowiges is baie verrykend en opbouend.

\subsubsection{Goeie kommunikasievermoëns}

Om die Woord effektief tot mense te bring sodat hulle daardeur opgebou word, is dit nodig om effektief te kan kommunikeer (Nel, 1994:83). Pieterse (1992a: 20-22) toon aan dat kommunikasie in wese 'n dialogiese karakter het. Daarom moet die ouderling nie net geleer word om bloot 'n Skrifboodskap te bring nie; die ouderling moet ook leer om te luister en die probleme van die lidmaat vanuit die Woord benader. Burger (1995:93) toon dat die dialoog eintlik 'n trialoog is: God is ook in die gesprek betrokke omdat Hy 'n roeping het met sowel die ouderling as die gelowige wat toegerus word.

In sy eenvoudigste vorm bestaan kommunikasie uit 'n sender, 'n boodskap, 'n medium, 'n kanaal en ontvanger (Venter, 1993:248). Doeltreffende kommunikasie is dus om die essensie van die boodskap vanaf die sender tot by die ontvanger deur die medium en kanaal te kry.

Mense kommunikeer verskillend in verskillende situasies en die boodskap kan versteur word op die weg (in die kanaal) vanaf die sender na die ontvanger. Daarom moet ouderlinge (senders) opgelei word hoe om te kommunikeer in die situasies waarin hulle hulle gaan bevind sodat doeltreffende oordrag van die boodskap aan die lidmate (ontvangers) kan plaasvind. Dit is situasies soos huisbesoek, gesprekke met mense wat siek is, mense wat rousmart ervaar, depressie het, ensovoorts. Verder is dit van belang dat wegbeweeg moet word van 'n outoritêre styl wat somtyds by ouderlinge voorkom (Beukes, 1997:687). As die ouderling die lidmaat met empatie benader, sal dit soveel makliker wees om Christus aan die lidmaat te bedien en die lidmaat sodoende toe te rus.

Toerusting kan weer eens formeel óf informeel wees. Formele toerustingsgeleenthede kan gereël word waar op sistematiese wyse spesifiek aan gesprekvoering in sekere situasies aandag gegee word. Informele toerusting kan plaasvind deur lektuur beskikbaar te stel oor die onderwerp en gesprekke daaroor aan te moedig.

\subsubsection{Goeie interpersoonlike verhoudings}

Een van die aspekte wat die boodskapoordrag (kanaal en medium) vanaf die ouderling (sender) na die lidmaat (ontvanger) beïnvloed, is die interpersoonlike verhouding wat daar tussen die ouderling en lidmaat is. Om met mense te werk, word mensekennis benodig. Daar moet sensitiwiteit vir interpersoonlike/menseverhoudings wees (Nel, 1994:71). 
Wood (1995:xvi-xvii) toon aan dat persoonlike verhoudings iets is wat deur kommunikasie ontstaan maar dat kommunikasie nie die enigste bepalende faktor nie. Ander faktore is: persoonlikhede, waardes, wyses van konflikhantering en kontekstuele beperkings. Verder is dit belangrik om op te let dat interpersoonlike verhoudings 'n proses is. Dit vorm oor 'n bepaalde tyd.

Hieruit kan afgelei word dat die ouderling deur kommunikasie aan die verhouding tussen hom en die lidmaat moet bou. Sowel ouderling as lidmaat moet presies verstaan dat hulle in 'n Godgegewe toerustingsverhouding is waar Godgegewe waardes en wyses van konflikhantering bestaan. Die ouderling moet besef watter waardes en persoonlikheid die lidmaat het waarmee hy werk. Hy moet leer hoe om verskillende tipes persoonlikhede te hanteer. Hy moet bewus wees van die beperkings wat daar op die verhouding tussen hom en die lidmaat rus.

Die beste manier om hierdie gawes te ontwikkel is deur kontak met mense. Daarom kan van dienswerkers verwag word om goeie informele omgang met ander mense te hê. Ouderlinge moet aangemoedig word om te sosialiseer en hulle nie af te skei van ander mense nie. Jy kan mense net leer ken indien daar direkte kontak met hulle is.

Formele onderriggeleenthede moet geskep word. Tydens 'n formele toerustingsgeleentheid kan 'n gelowige wat spesialiseer in mensekennis (bv. 'n Christenpsigoloog) die besondere dienswerkers kom toerus oor sake soos lyftaal, gevoelsmerkers en hoe om sekere tipes mense te benader.

\section{Samevatting}

Dit is duidelik dat die werk van die ouderling van groot belang in die opbou van die gemeente is. Die werk wat die ouderling verrig, is die "spalk" om lidmate tot funksionering in die liggaam van Christus te bring en hierdie liggaam sodoende op te bou. Tog moet die ouderling self ook eers toegerus ("gespalk") word voor hy doeltreffend kan funksioneer. In die artikel het dit duidelik geword dat toerusting op verskillende wyses plaasvind. Dit het duidelik geword dat alhoewel God mense roep tot sy diens en Hy hulle deur sy Gees toerus, dit nie moet lyk asof die geroepe persoon net een oggend opgestaan het en die dienswerk kon doen nie. Menslik gesproke, was daar altyd 'n vorm van opleiding en toerusting en hierdie toerusting is dan deur ander mededienaars onder leiding van die Gees gedoen.

Toerusting deur mededienaars vind op verskillende wyses plaas: Dit kan op formele óf informele wyse geskied. As toerusting op formele wyse aangebied word, is dit meestal gesistematiseer. Formele toerusting vind meermale eenmalig plaas, informeel - meer voortdurend. Miskien moet daar aandag gegee word om voortdurend formele toerustingsgeleenthede te skep. 
Daar is bepaal watter gawes nodig is om die besondere dienswerk van ouderling te doen. Daarna is gekyk na maniere waarop die gawes ontwikkel en toegerus kon word. Op oorsigtelike wyse is gepoog om riglyne te gee waaraan en waarvolgens die toerusting van ouderlinge in die kerk kan plaasvind.

Hierdie is maar net enkele gedagtes om voortdurende toerusting van dienswerkers in die gemeente te stimuleer en daarom moet dit uitgebrei word volgens die unieke omstandighede van elke selfstandige kerk. So sal die gelowiges toegerus word deurdat die besondere dienswerkers (soos in Ef. 4:1112 gestel) daartoe in staat sal wees om hulle toe te rus en op dié wyse sal die liggaam van Christus Skriftuurlik opgebou word tot eer en verheerliking van die Drie-enige God.

\section{Bibliografie}

ADAMS, J.E. 1978. Shepherding God's flock 3. Pastoral leadership. Grand Rapids, Michigan : Baker.

AITKEN, K.T. 1997. Elder (zaqen). (In Van Gemeren, W., ed. New international dictionary of Old Testament theology and exegesis. Volume 1. Grand Rapids, Michigan : Zondervan. p. 1137-1139.)

ASKES, H. 1993. Die taak van die ouderling vandag: enkele grepe soos gesien deur 'n ouderling. Ned Geref Teologiese Tydskrif, 34(4):532-541.

BOUWMAN, H. 1928. Gereformeerd kerkrecht. Kampen : Kok.

BEUKES, M.J. du P. 1997. Kerkleiding in die een en twintigste eeu. Hervormde Teologiese Studies, 53(3):670-690.

BURGER, C. 1991. Die dinamika van 'n Christelike geloofsgemeenskap. Nuut gedink oor gemeentes. Kaapstad : Lux Verbi.

BURGER, C. 1995. Gemeentes in transito. Vernuwingsgeleenthede in 'n oorgangstyd. Kaapstad : Lux Verbi.

COERTZEN, P. 1995. Ampte in die kerk. Ned Geref Teologiese Tydskrif, 36(3):343-352.

FIRET, J. 1974. Het agogisch moment in het pastoraal optreden. Kampen : Kok.

GROSHEIDE, F.W. 1950. De handelingen der Apostelen. Tweede deel. Korte verklaring der Heilige Schrift. Kampen : Kok.

HENDRIKS, H.J. 1990. Bedieninge in en deur die gemeente. 'n Praktiese-teologiese basisteorie. Praktiese Teologie in Suid-Afrika, 5(1):19-42.

HENDRIKS, H.J. 1997. Kerklike "megatrends": bedieningsimplikasies. Ned Geref Teologiese Tydskrif, 38(1):27-38.

KLEYNHANS, E.P.J. 1984. Gereformeerde kerkreg. Deel 2: Kerk en amp. Pretoria : N.G. Kerkboekhandel.

LOUW, J.P. \& NIDA, E.A. 1988. Greek- English lexicon of the New Testament based on semantic domains. Goodwood, Cape : United Bible Societies.

MARSHALL, I.H. 1991. 1 Peter. The IVP New Testament Commentary Series. Illinois : InterVarsity Press.

NEL, M. 1994. Gemeentebou. Halfway House : Orion.

PELSER, G.M.M. 1990. Die bedieninge in die Nuwe Testament. 'n Ondersoek na historiese wording en prinsipiële regverdigbaarheid. Praktiese Teologie in Suid-Afrika, 5(1):1-18.

PIETERSE, H.J.C. 1992a. 'n Prakties-teologiese kommunikasieteorie vir die prediking. Praktiese Teologie in Suid-Afrika, 7(1):17-25.

PIETERSE, H.J.C. 1992b. Woord en werklikheid in die moderne Praktiese teologie. In die Skriflig, 26(3):325-335. 
RAUBENHEIMER, O.S.H. 1987. Persone en instansies betrokke by gemeentebou. Praktiese Teologie in Suid-Afrika, 2(1):38-53.

RIENECKER, F. 1980. A linguistic key to the Greek New Testament, vol. 2. Grand Rapids, Michigan : Zondervan.

ROBERTS, J.H. 1990. Die brief aan die Efesiërs. Skrifuitleg vir die Bybelstudent en gemeente. Kaapstad : N.G.Kerk-Uitgewers.

SHAWCHUCH, N. \& HEUSER, R. 1993. Leading the congregation. Caring for yourself while serving others. Nashville : Abingdon Press.

SPOELSTRA, B. 1989. Gereformeerde kerkreg en kerkregering. Handboek by die kerkorde. Hammanskraal : HTS.

SWANEPOEL, A.C. 1996. Eietydse ampsbediening en bedieningstrukture vir ouderlinge en diakens in die Nederduitse Gereformeerde Kerk - 'n kerkregtelike perspektief. Ned Geref Teologiese Tydskrif, 37(1):104-114.

TOWNER, P.H. 1994. 1-2 Timothy \& Titus. The IVP New Testament Commentary Series. Illinois : InterVarsity Press.

VAN GENDEREN, J. \& VELEMA, W.H. 1992. Beknopte gereformeerde dogmatiek. Kampen : Kok.

VAN NIEKERK, A.A. 1992. Christenskap en leierskap. Ned Geref Teologiese Tydskrif, 33(1):126-133).

VENTER, C.J.H. 1993. Basisteoretiese perspektiewe op kommunikasie in die bediening. In die Skriflig, 27(2):247-260).

VORSTER, J.M. 1997. Die diens van die Gereformeerde predikant. In die Skriflig, 31(3):267-291.

VORSTER, J.M. 1999. An introduction to Reformed Church Polity. Potchefstroom : Potchefstroom Teologiese Publikasies.

WOOD, J.T. 1995. Relational communication. Continuity and change in personal relationships. Belmont, California : Wadsworth. 